Jan Hanska, Doctor of Social Sciences, Major, in second Doctoral Program at National Defence University, Helsinki, jan.hanska@mil.fi

\title{
NARRATIVE APPROACH TO THE ART OF WAR AND MILITARY STUDIES- Narratology as military science research paradigm
}

\section{Key words}

narrative, linguistic turn, research paradigm, narratology, intertextuality, military studies

\begin{abstract}
The purpose of this article is to initiate discussion into the role narratives could play in military studies. Narratology is an old and well-established research paradigm that first emerged as part of the linguistic turn. Yet its potential has not been depleted. It is the study of narratives or stories. There are plenty of topics not yet approached from this perspective especially in the field of military studies. The military academia needs to broaden its scope of research and allow for alternative orientations and theories to be used to address traditional dilemmas, create new research paradigms and enrich the variety of analysis. Critical security studies approach shared topics with military studies by embracing the aesthetic turn that differentiates between the representation and the represented. The argument in this article is that to produce comprehensive information on its research topics military studies would benefit from embracing them as people experience them and not focus on their ontology. The article does not offer a methodological toolbox to the reader but rather an introduction to some classics of narratology and offers a few insights how this type of approach could be used in military history, strategy, operational art or even leadership studies.
\end{abstract}

It is present at all times, in all places, in all societies; indeed narrative starts with the very history of mankind; there is not, there has never been anywhere, any people without narrative; all classes, all human groups have their stories [...] Like life itself, it is there, international, transhistorical, transcultural. (Barthes 1977:79) 
There is a tradition to view war as an art but seek for methods that can subject it to scientific analysis. J.F.C. Fuller, for all his esotericism, sought to develop a science of war because only when we think of war scientifically do we become true artists of war. Few soldiers can become trained scientists, but as Fuller argued, if we spent half the time we spend in playing games to study science and philosophy, we could produce a very fine crop of generals. (1926:16)

The Russian and Soviet approach to war has always been scientific but tends to focus on mathematical equations of ratios of force. (See eg. Triandafillov 1994:7) The mechanics of war has been theorized since the days of Jomini in the early $19^{\text {th }}$ century (1992) but philosophical approaches beyond the oriental classics have been rare and sporadic. (Clausewitz 1989 and Sawyer ed. 1993) The purpose of this article is not to question the classical thinkers but to describe and justify an alternative approach to the study of the art of war. War is a social phenomenon. Societies and states wage war against each other and individual humans are the primary protagonists even today when machines and computers dominate the battlefield. If we view war as social interaction and continuation of policy, we can use methods of research from social sciences.

Beginning in the 1960's social sciences have undergone a linguistic turn and language has increasingly become a focus of research. On the crest of this wave rode narratology. Old Russian formalists have been resurrected and found anew in the West. Biggest fervor of the narrative revolution has mellowed down but we experience a new interest in narratology. This time passion has been replaced with cool analysis. Narratology has cast off its mania for taxonomies and structuralists' attempts to analyze the text to its minuscule details.

Narratology today is an open-ended project that at its best focuses on deciphering stories that earlier were not even considered narratives. Now the focus has shifted into narrativity of the texts to analyze how easily they can be perceived as stories. Further distinctions concerning terminology will be made in the course of this article. By multidisciplinary approaches narratology is able to enrich various fields of research. (Herman 1999:2-3) Military sciences should not remain isolated. Narrative approach offers new conceptual tools and can help pose new questions to keep military sciences in motion and unceasing development. 
According to Thomas Kuhn's idea of paradigm shifts in sciences, in each field of research the invention of a new paradigm leads to a veritable revolution in research methodology. (1970) While in many fields of military science the connection to their "civilian counterpart" is well established, others are in the pre-paradigmatic stage. Military history exemplifies the former and tactics and operational art the latter. Both can be enriched with addition of new methods into the toolboxes they use to disseminate their data.

Nevertheless, narratology is not a unified theory. Neither is it a method of research. It is rather a view of the world and a mental disposition toward data. There are many ways of interpreting and expressing the narrative orientation to research. Even the process of reading our data can be seen as writing it anew. (Czarniawska 2004:88) No matter how scientific our work is, the research report is always a narrative. We work on texts that represent only a selected and simplified reality and this narrated reality is turned into another narrative. (Riessman 1993:15)

We must recognize, that in all research where written material is the main corpus of data, to a certain degree literary studies and narratology offer a viable viewpoint. Every text is plurivocal by their nature and can be deconstructed, interpreted, understood and analyzed in a legion of ways. (Riessman 1993: 15) Military history is a sphere in which we struggle with this problem. We immerse ourselves in archives and use diaries and memoirs to verify the "truth" of a long-gone battle. Everything is checked and cross-checked, every morsel of information is verified by another source unlikely "contaminated" by the other. (Lauerma 1977) After all this painstaking work we sit down to write and "storytelling, to put the argument simply is what we do with our research materials." (Riessman 1993: 1)

There is a long tradition of re-interpreting old classics like Sun-Tzu, and violating the integrity of the text and the entire narrative discourse by inserting or extracting words regardless of their context without a thought given to the mechanisms of interpretation. Likewise, in many cases - like the debate concerning the use of Clausewitz since his $\mathrm{On}$ War is often self-contradictory one must comprehend that narratives always simplify complex issues and not all words or sentences are important in a text. (Rabinowitz 1987:19-20, 48) To understand a text requires more than summing up its partial meanings. The text 
always has to be considered as a unified whole under a hierarchy of topics. (Ricoeur 1995:38)

Narratology has traditionally focused on invented stories or fictional narratives. This is an obstacle the researcher has to bypass in justifying his methodology. This type of thought originates in viewing fictional narratives as exemplary models. Gerard Genette focused his attention to whether applicability of results or methods of narratology fit into examining factual or fact-based narratives. (1993: 54-84) Stories often attempt to blur the distinction between fact and fiction. Because of this inbuilt tendency the methods of studying fictional narratives can be used effectively to study factual narratives as well.

To the ones who discredit such humanistic tendencies of research I argue that narrative works as a medium of communicating information and experience to others. Distinguished officers A.F. Airo, Lennart Oesch and Aarne Blick worked as editors-in-chief of widely read periodical Kansa taisteli-Miehet Kertovat, that was published for almost thirty years. They saw the value of firsthand experience and wanted to ensure its availability for future generations. Alasdair MacIntyre claimed that "man is in his actions and practices, as well as in his fictions, essentially a story-telling animal" (1984:216) Storytelling comes naturally to us and works as a vessel of collective memory. This veritable library of empirical experience of memories, written, oral, factual or fictional should be fully taken advantage of by military sciences.

This article will not focus on analysis of texts but on the extraliterary aspects of narrative. A huge corpus of narratological theory on the elements within the literary structure of the narrative exists. Two such approaches are formalists and structuralists. (Barthes 1977, Greimas 1983 and Propp 1968) This article will illustrate certain narrative-oriented ways of thinking and possibilities how narratives could be interpreted, used and researched. New-wave narratology emphasizes escaping the rigidity of text and its structure of words and sentences. Even the Roland Barthes who initiated the French structuralist movement is far removed from the latter Barthes who sought for pleasure in the text and considered the free play of the text erotic. (1990) 


\section{What is a narrative?}

It is not sufficient to declare that something can be interpreted and studied as a story. Barbara Czarniawska notes that there is a tendency to do studies that merely show the presence of stories in the data. To create high-class research the point should be what the consequences of storytelling are for those who tell them, and those who study them. (2004:40-41) Books of great captains from memoirs to theoretical treatises have widespread influence. Much has been written about clausewitzian connections of U.S. doctrine, but the development of ideas from one theory to another remains quite uncharted. Original ideas in tactics affect lives of men and destinies of nations.

There are virtually countless "definitions" of a narrative. Basic description is the classic Aristotelian claim of having a definite beginning, middle and an end. (1940:17-18) Generally a narrative is a representation of two or more real or fictional events in a time sequence. Often a transition from one state to another caused or experienced by actors is presupposed. Nothing would have a meaning if no one witnessed it or caused it. Yet events alone don't create a very meaningful narrative or a text composed entirely of actions a story. (Prince 1992:4, Bal 1997:182, and Herman 2002: 82-84)

Tzvetan Todorov's description of an ideal narrative begins with a stable situation disturbed by some outside force that leads to a state of disequilibrium. Another force then restores equilibrium. The second state of equilibrium is not identical to the first, although it is quite similar. (1981:51) A narrative begins with an orientation, has actions that complicate it and build interest into an apex and finishes with a coda or a resolution section. Labov and Waletzky argue that a narrative which "contains only an orientation, complicating action, and result [...] lacks significance: it has no point."'(2006:28) The narrative should be told in response to some outside stimulus and to establish some personal point of interest. It often emphasizes the strange and unusual character of the situation and should contain the means to make its importance explicit. (Labov Waletzky 2006: 29)

The most famous and the most simplified narrative in the history of war was the summary of an entire campaign by Julius Caesar in three words: "Veni, vidi, vici." It indirectly implies to the status quo before Caesar's arrival and explains 
it. It also hints to the equilibrium created. Instead of only one there are three different actions; arriving, seeing and conquering. While this story is in its simplicity more elaborate than required, it is still not very interesting.

The Aristotelian notion of story has a meaning to the researcher. If there are no beginnings, middles and ends, he has to set them in place to limit his research. The beginning is an extremely sensitive point in any narrative (Barthes 1977:129) but ending the story timely has to be accomplished, too. By making the right choices, the narrator dictates the contents of the story so, that nothing of importance to the entire narrative discourse is excluded but the amount of data remains comprehensible and manageable.

The need for endings is omnipresent. We expect the stories to end. In the case of military history and studies of campaigns and wars the ending is superimposed at the latest by a peace treaty. Yet the world is presented to us as mere sequence without beginning or end or alternatively as sequence of beginnings that never truly conclude. (Polkinghorne 1988:68) Storytellers and narratologists emplot these sequences and artificially insert beginnings and endings so as to best fit the story

However, the more political the intention of a story, the more the story may remain in motion. To be a useful tool of manipulation the narrative must always "be unfolding, a perpetual process of renegotiation, reconstruction and retelling."(Andrews 2007:189) In a story one should perhaps not search for a proper ending but rather a point of closure from which the story can continue indefinitely in a new direction. (Derrida 1988:21-22) Barthes criticized the Western need of "writing 'the end."'(1974:52) In our cultural model there seems to be a necessity to participate in setting forth the end of every action.

Today the idea that narration would require a structural integration from beginning to end seems questionable. If narrative methods are to be used outside the realm of traditional stories, the definitions of the story must evolve as well. The story no longer has to follow the Aristotelian definition, because our literature has evolved (or regressed) to a point where a wider variety of texts are recognized as stories. Additionally our worldview allows for stories to take new directions at each point of closure and continue further and further. After all, how could the hypertext ever end? 
The most common distinction made in narratology between the sequence of actions or events told about, and the means by which these are told, is the "story-discourse dichotomy." It is usually portrayed so that "story" refers to characters, events, and settings, or the content, and "discourse" refers to the form of expression, presentation, or narration of the story.(Polkinghorne 1988: 90-91) Gerard Genette commonly uses récit translated as "narrative". For him narrative means three different things. First it refers to narrative statement in oral or written discourse, which undertakes to tell of an event. Secondly it refers to the succession of real or fictitious events, which are the subjects of discourse, and to their interrelations. Thirdly it refers to an event that consists of someone recounting something; the act of narrating itself. (1980:25-26) His choice of vocabulary uses "story" to refer to the signified of narrative content, and "narrative" for the signifier, statement, discourse or narrative text itself. (1980:27)

Seymour Chatman called a story the "content or chain of events (actions, happenings), plus what may be called the existents (characters, items of setting)" and discourse "the means by which the content is communicated. In simple terms, the story is the what in a narrative that is depicted, discourse the how."(1978:19) Certain rules are needed to turn individual words into sentences, and only the level of discourse, with its own rules, is able to produce higher-order meanings. Creating this order requires the presence of a hearer and speaker, who draws on communal conventions, with the mutual expectation that both symbolize meaning according to the same set of transforming covenants. Only then narrative meaning emerges from the discourse.(Polkinghorne 1988:32-33)

Among narrative theorists there is a wide variety of tendencies concerning the use of terms "story" and "narrative." Jerome Bruner uses the two terms synonymously. (2006:99) Shlomith Rimmon-Kenan distinguishes story, text and narration from each other. Story is essentially a succession of events abstracted from the text and reconstructed in their chronological order, and a text is a spoken or written discourse, which undertakes the telling of these events. The text is "what we read". Within a text, there may not be chronological order. The story recipient superimposes it during interpretation. (1983:3-4) I use the definition that a story is a mental representation and narrative a mediated representation requiring a narrator and some form of 
narration to be present. A text can be either written or spoken, and thus implies someone who speaks or writes. Yet many other things create narratives. Comic books tell stories without words. Images and music can be treated as texts. (Barthes 1977) Since narratology has broken free of its former methodological restraints, we should employ it to analyze new types of data. The doctrines that describe GOP and COPD operational planning processes used by NATO are certainly texts and according to this typology they are narratives as well, but what is it they tell?

\section{Art of war as a textual mosaic}

Emplotment of events is such an integral part of our everyday experience that we fail to notice the process but experience the product. Plotting shapes temporal happenings into meaningful units. E. M. Forster uses a simple example of a dying king and queen to clarify the basic concepts. "The king died. The queen died." These are just statements or descriptions of individual events. "The king died and then the queen died" is a narrative. "The king died and then the queen died of grief" adds a plot. When we consider the death of a queen, if it happens in a narrative, we tend to ask "and then?" If in a plot, we ask "why"? (Forster 1953:82-83)

While a story can be seen as an emplotted narrative, in practice the separation of the authentic from fictional, the events and their interpretation, is always theoretical. (Genette 1993:27) A story is made out of events by the plot. The plot governs a succession of events within any story and connects them. (Ochs Capps 2001:207) In the example of GOP or COPD the process itself, the succession of different planning phases, turns the planning into a story. A meaning is created through the causal succession offered by the form or structure of the process itself. The flowchart of the planning process works as a plot.

All plots are not that simple. A plot can weave historical and social contexts and thoughts and feelings of people into the narrative. (Czarniawska 2004:125) This means that most texts have several interweaved plots that have to be interconnected in some manner by the narrator and the story recipient. As Barthes writes, 
To interpret text is not to give it a [...] meaning, but on the contrary appreciate what plural constitutes it. [...] the networks are many and interact, without any one of them being able to surpass the rest; this text is a galaxy of signifiers [...] we gain access to it by several entrances, none of which can be authoritatively declared to be the main one. (1974:5)

A text is created of multiple writings concentrated anew in one focal point. This point is the reader and not the author as conventionally has been thought. The unity of the text is not in its origins but in its ending, the unspecified reader. (Barthes 1993:114-117) In reading Jomini, we hear a multitude of other military thinkers, past and present and interpret him based on all the military knowledge we have gained. Thus a text is not a line of words releasing a single meaning but rather "a multi-dimensional space in which a variety writings, none of them original, blend and clash. The text is a tissue of quotations drawn from the innumerable centres of culture."(Barthes 1977:146)

This highlights the concept of "intertextuality" - the relation of a text to all other texts. Julia Kristeva argued that text "takes shape as a mosaic of citations, every text is the absorption and transformation of other texts."(cit. Culler 1975:139) But which ones? No answer exists, since it depends on the story recipient. His knowledge of other texts sets the limits to which texts can participate in the play of intertextuality. The more limited the "internal library" of the story recipient is, the easier it is for the narrator to quote, borrow, and steal from other texts to his benefit. This is why well-read Liddell Hart still manages to enjoy fame, while he copied other theorists. In operational art this is proper behaviour, in academic military studies a severe infringement. But how does this free flow of ideas from one text to another occur?

A narrative is never neutral and free from aspirations and evaluations. It arrives from another context saturated with other people's interpretations. (Todorov 1981: 24) Every speaker is simultaneously a respondent. Everyone has to presuppose the preceding utterances he enters into a relationship with. This relationship may consist of building on them, disagreeing with them, or simply presuming the listener has knowledge of them. Thus, any utterance is linked to a complex chain or a web of other utterances that can be repeated with varying means of interpretation. (Bakhtin 1986:69,91) The text is unique because it reflects all texts within the bounds of a given sphere, and all ideas are 
interconnected. (Bakhtin 1986:105) As Barthes writes "nothing exists outside the text, there is never a whole of the text."(1974:6) The text is plurivocal; a text is indeed a network woven out of other texts and other voices.(Barthes 1974:21)

This is how we should treat and use the works of tactics and operational art. Instead of blind admiration of Milan Vego (2009) to give his text the credit it deserves we should employ intertextuality. We must acknowledge that a multitude of voices conjoin to tell the story of joint warfare. Only by reading the older classics of tactics and military strategy we understand how ancient views are adapted and adopted anew to answer the demands of the situation. To invent new methods in operational art the military scientist must be acquainted with what has been written, tested, and tried before.

According to Frederic Jameson, all texts, including doctrines, come before us as "always-already-read; we apprehend them through sedimented layers of previous interpretations," Even a brand-new text is interpreted according to "commonly accepted reading habits and categories developed by those inherited interpretive traditions." (Jameson 2002:ix-x) If classics like Fuller or Clausewitz do not guide the interpretation of Vego, the reader is an ignoramus. Vego connects to older classics because he has built his interpretation upon them. This is what all officers should do; first acquaint themselves with existing interpretive traditions to be able to situate a tactical text in its proper context. Second, they should use literary methods to avoid the pitfalls and limitations of traditional interpretive traditions and attempt to search for new meanings. The need for new interpretations of military classics is a prerequisite of creating something new in operational art.

Here it will be worthwhile to introduce one more conceptual tool; that of a metanarrative. It can be defined as a narrative superstructure above other narratives. A metanarrative is a "master narrative" that influences all other narratives told about its contents. If a narrative creates a storyworld the metanarrative is responsible for the entire storyverse it belongs to. (Hanska 2012) Expressions like "grand narrative", master narrative" and even "sacred story" (Gutterman 2005) are used practically synonymously to describe a narrative "above others" and by its very existence able to shape the others. For example Clausewitz has produced a metanarrative for tactics, since his text is impossible to exclude from any subsequent narrative on tactics. 
$\mathrm{He}$, Sun-Tzu, Jomini and others suffer a misdemeanour, since the texts remain but their authors can't provide guidance for interpretation. The texts have a revered status. Todorov pointed this out with Poetics by Aristotle. It was "exhumed and made to play the role comparable to that of holy writ." (1981:xxiv) Text can become a prisoner of its own elevated status. Because it is so celebrated, nobody dares to contest it, or even bother reading it. It becomes a source of quotations and clichés that, removed from their context, betray the author's thought. (Ibid.) The classics of strategy and tactics suffer this same fate. The text is not treated as a completed utterance, but chopped into parts suited to fit the users' purposes. The text is commonly encountered only as "stories" that are told and circulated about it. Thus the story about Sun Tzu's art of war has been twisted in numerous re-tellings into something utterly different, which begins a life of its own and becomes a dogma. To get beyond shallow interpretations or stories about the classics we need to reacquaint ourselves with the original texts using suitable interpretative tools to dissect these metanarratives.

\section{Turning military history into histoire}

The story can have either narrativity or narrativehood, or both. Narrativehood is the difference between sequenced events or scripts and a narrative, the essence of what makes a story a story. Narrativity means how readily a narrative can be processed as one. (Herman 2002:86) Narrativehood is a binary predicate, something either is seen by the story recipients to be a narrative or not. Narrativity is scalar, so that a story can be more or less story-like. Narrativity is connected to the idea of "canonicity and breach," To attain maximal narrativity, the story has to have a balanced combination of both. As Jerome Bruner wrote, to be worth telling a tale "must be about how an implicit canonical script has been breached, violated or derived from."(1991:11) Story loses narrativity when it is either too stereotypical, or so "out there" that it amazes the story recipient. (Herman 2002:90-91) The ability to situate a story correctly is a prerequisite of its interpretation. Reading and understanding are based on conventions one may not even be aware of. These conventions can be thought of as implicit knowledge of both the reader and the authors. Whenever one writes something, one is engaged in some literary tradition, a genre that, "the author can write against, certainly, whose conventions he may attempt to subvert, but which is nonetheless the context within which his activity takes place." (Culler 
1975:116) Therefore, every writer operates with a genre or genres that shape his story. Doctrines, for example, are not often perceived as a separate genre. They tend to be low in narrativity, but can be processed as stories that adhere to their generic logic. The same applies to many texts produced by the military. Even if numbers describing money and resources spent don't readily fit the definition of a narrative, the yearly budget reports do. Narrative orientation occasionally requires a bit of creativity, but many types of data can be studied without overtly straining one's imagination.

Military sciences are currently both looking for their roots and attempting to push their limits. The internal ontological debates continue. Military history is one of the more traditional branches. Practically everything is history. Each tick-tock of the clock turns the present into past history. Since ars is longa and vita brevis most of history is not directly accessible to us through memory. History needs to be storied to be communicable to those with no direct personal link to its states, events and actions.

Here the concept of metahistory, popularized by Hayden White (1973), emerges. The historian proper is confined to human events and always looks for a human cause. He works inductively, trying to avoid any forming patterns, except those evident in the facts themselves. The metahistorian, like a poet, works deductively by seeking to impose a certain pattern on his subject. If he writes a tragedy, he imposes a tragic pattern. He chooses a certain historical, legendary, or contemporary theme to give his story perspective. To describe the rise and fall of the Third Reich, one can utilize the ancient storyline of tragedy, where the protagonist is flawed to begin with and his fall is inevitable. To praise the survival struggles of a small nation like Finland or Vietnam against a powerful aggressor, the plotline of romance is preferable. (see Frye 1957)

If we treat history as an exact science in which total objectivity somehow surpasses human tendency to err, we have to discard Homer, Thucydides and Josephus among other classics as mere poets. However, Northrop Frye sees similarities between a historian and a poet because essentially both imitate actions in words. The difference is that the poet "makes no specific statements of fact, and hence is not judged by the truth or falsehood of what he says." The poet "imitates the universal, not the particular; he is concerned not with what happened but with what happens." (Frye 1969:114) He tells of things that tend 
to occur or should have occurred. He formulates his narrative so that he seems to narrate the events as a historian, but blends fact and fiction together taking poetic liberties. For most respectable historians poetry is feigned history, and metahistory the bastard offspring of the two. It's advisable to envision metahistory as having to poles, one in history proper and the other in poetry. (1969:117-119)

Due to the long debate about history being "objective truths told" or "subjectively told stories about the past" we might consider using Genette's "diction" to describe historical stories. (1993) People understand a historical text like a fictional story. (Polkinghorne 1988:51) The creative process is very similar in both. Before the historian is able to start "upon the data of the historical field the conceptual apparatus he will use to represent and explain it, he must first prefigure the field - that is to say, constitute it as an object of mental perception." (White 1973:33) To summarize, the world of history must be prepared for interpretation like any fictional storyworlds. The initial creative process of a historian and a teller of tales is the same.

Philosophically a fact or an event is such only under a description and any event can be described in numerous ways. (Martin 1987:73) Historical reality gets sullied as soon as humans try to process, store or communicate it. The meaning of the past cannot be found in the events themselves, but is has to be explained. As Riessman argues, "the "truths" of narrative accounts is not in their faithful representations of a past world, but in the shifting connections they forge among past, present and future" (2004:35) Narrators interpret the past, rather than produce it $t$ as it was. This applies both to those generals and marshals who wrote their war memoirs and military historians. Undoubtedly multiple versions of "the truth" is written in journals and war diaries and buried in archives. Still, the historian pieces his findings together and writes it into a narrative - his research report. By widening our scope of research we are able to include alternative versions of history and apply perspectives from other vantage points to decipher and understand the valuable lessons about art of war and how to apply them in contemporary contexts. 


\section{Turning stories into reality - leadership and strategy}

James Phelan sees narrative as rhetoric, and writes that the narrator is "telling a particular story to a particular audience in a particular situation for presumably, a particular purpose." (1996:4) This works as a definition of the use of narratives in leadership, albeit rhetoric and narrative are two different methods of persuasion. Rhetoric seeks to rationalize while narrative digs deeper into the psyche to incite emotions. To exaggerate, rhetoric attempts to convert the brain, while narrative sets the heart blazing.

A story has a certain form because it is told to certain people. (Riessman 1993:11) Since stories are told at particular times to particular people in order to affect them in a particular manner, they are given new forms and contents in every occasion. Narrative persuasion is just another way to persuade people to obey one's will and inflict real changes in the status quo. Bruner claimed that narratives, "once acted out, 'make' events and 'make' history. They contribute to the reality of the participants." (1986:42-43) Narratives change the world but do so subtly. By affecting the way people see the world they inhabit they create a need to try to change the world for the better. Many stories circulating in the world of politics belong to the realm of strategic communication and they always have a purpose.

Jean-Francois Lyotard asserted that "realism is the art of making reality, of knowing reality and knowing how to make reality." (1997:91) Reality is continuously reshaped with strategic narratives of the superpowers. These narratives turned Osama into a global threat or divided the world into the Western and Eastern blocs. Military and political ideologies are narrative-based and communicated accordingly. Barthes argued that "ideological systems are fictions [...] classical novels, packed with plots, crises, good and evil characters [...] every fiction is supported by a social jargon, a sociolect, with which it identifies." (1990:27-28) When it comes to the values associated with the given way of talking the sociolect can be referred to as "the norms of the text". There are numerous sociolects but usually one dominates others. The idea of independent and unallied defence for Finland is one, but so is pacifism. The sociolects do not exist in harmony; they fight for supremacy and produce counter narratives. Barthes wrote that 
"if power is on its side, it spreads everywhere in the general and daily occurrences of social life, it becomes doxa, nature: this is the supposedly apolitical jargon of politicians, of agents of the state [...] even out of power, even when power is against it, the rivalry is reborn, the jargons split and struggle among themselves." (1990:28)

To listen to a narrative is to listen to values associated with a given sociolect. (Phelan 1996:43) Stories are told by narrators so repetitively that they eventually become stereotypes of themselves. The ideology of unallied defence was summarized by General Adolf Ehrnrooth: "Finland is a good country. It is the best one for us Finns. It is worth defending and its only defender is the people of Finland." (Ehrnrooth - Lehtonen 1995) Many individuals told the same narrative, but Ehrnrooth's was easily distinguishable among these multivoiced and repetitive tellings. The ideology spreads with the narrative. To choose to listen to Ehrnrooth is to invite the values embedded in his narrative to enter one's cognition. According to Bakhtin "the life of the text, that is, its true essence, always develops on the boundary between two consciousnesses, two subjects." (1986:106) A text is dialogic, and to produce a meaning, there needs to be a text-mediated exchange of values between the narrator and his story recipient. Thus, the story recipient makes a decision consciously to allow the sociolect to influence him and the ultimate meaning is produced in this "conversation" with the reader.

Robert Bathurst (1996) introduced the concept of "fabulation" meaning that a culture tells a story of itself, its place in the world, its heroes and achievements, and by doing this creates its reality. The result is often seen as the history of the nation, while it is only a fable of how the nation wants to see itself. Historical discourse merely cultivates the "reality effect." Narrative structure itself becomes the sign and the proof of reality. (Dolezel 1999:249) These narratives about the identity of the nation become metanarratives that shape our existence and how we narratively discuss ourselves. Only by critical introspection is a culture able to evaluate its situation. Is Finland as independent today as it imagines? No, in terms of political alliances, since it joined the EU. In military matters the question is relevant. Old metanarratives have a mastery over the telling of new stories - at least the official ones of governmental institutions.

Lyotard argued that ever since World War II "the grand narrative has lost its credibility, regardless of what mode of unification it uses, regardless of whether 
it is a speculative narrative or a narrative of emancipation." (1984:37) Lyotard wanted to discard these metanarratives and, along with their deterioration, allow alternative narratives to rise in form of hitherto silenced stories. (1993) Narrative itself did not lose its validity, but the types of narratives deemed important switched to "little narratives." (Czarniawska 2004:13)Yet old metanarratives thrive. Jameson claimed that they are buried but still alive in the political unconscious. (1984:xi-xii) Post-modernity is characterized by incredulity towards metanarratives in legitimating knowledge. (Lyotard 1984:xxiii-xxiv) But how many of us truly are living in post-modernity? We still allow the metanarratives to shape our existence. As researchers it would be a major achievement to locate and dissect some of the military metanarratives and to analyze whether they are viable today. The benefit derived from this is not restricted to academia, but will increase our practical competence as leaders and soldiers.

\section{Coda}

It is time to start bringing this narrative or article to its point of closure. As in life or military sciences themselves, there is no definite ending where all stray plotlines would be knitted together. This article attempted to provide an alternative methodological approach for aspiring military researchers to consider as a possible means of conducting their study. I attempted to incite interest in some readers to get acquainted with the classics of narratology and not to offer a "Swiss army knife" type of tool ready-to-use. Narrative orientation is a rather new research paradigm in military sciences. It has not been widely employed and has huge potential. But it is demanding for the aspiring researcher since first he has to build his own analytical tools suitable for the types of narratives he wishes to study. Military sciences are living a renaissance of their own with the growth of National Defence University as a research institution and thus internal academic debates benefit everyone. This article has been an invitation to commentary since narratology, just as the narratives it researches, requires criticism to grow and bloom.

\section{References}

Andrews, Molly (2007). Shaping History: Narratives of Political Change. Cambridge: Cambridge University Press. 
Aristotle (1940). Poetics. Ed. Rev T. A. Moxon. London: J. M. Dent \& Sons Limited.

Bakhtin, Mikhail (1986). Speech Genres and Other Late Essays. Austin: University of Texas Press.

Bal, Mieke (1997). Narratology: Introduction to the Theory of Narrative. Toronto: University of Toronto Press.

Barthes, Roland, (1974). S/Z. Translated by Richard Miller. New York: Hill and Wang.

Barthes, Roland (1977). Image Music Text. New York: Hill and Wang.

Barthes, Roland (1990). The Pleasure of the Text. Oxford: Basil Blackwell.

Barthes, Roland (1993). Tekijän kuolema, Tekstin syntymä. Tampere: Vastapaino.

Bruner, Jerome (1986). Actual Minds, Possible Worlds. Cambridge: Harvard University Press.

Bruner, Jerome (1987) [2006]. Life as Narrative. In Sage Benchmarks in Social Research Methods - Narrative Methods, Volume 1, Narrative Perspectives, eds. Paul Atkinson \& Sara Delamont. London: Sage Publications.

Bruner, Jerome (1991). The Narrative Construction of Reality. In Social Research 54(1):11-23

Chatman, Seymour (1978). Story and Discourse: Narrative Structure in Fiction and Film. Ithaca and London: Cornell University Press.

Clausewitz, Carl von (1989). On War. Edited and translated by Michael Howard and Peter Paret, First paperback edition, Princeton: Princeton University Press.

Culler, Jonathan (1975). Structuralist Poetics: Structuralism, Linguistics, and the Study of Literature. Ithaca: Cornell University Press.

Czarniawska, Barbara (2004). Narratives in Social Science Research. London: SAGE Publications Ltd.

Derrida, Jacques (1988). Positioita. Helsinki: Gaudeamus.

Dolezel, Lubomir (1999). Fictional and Historical Narrative: Meeting the Postmodernist Challenge. In Herman, David Ed. (1999) Narratologies: New Perspectives for Narrative Analysis 247-273. Columbus: Ohio State University Press.

Ehrnrooth, Adolf - Lehtonen, Marja-Liisa (1995). Kenraalin testamentti. Helsinki: WSOY.

Forster, E. M. (1953). Aspects of the Novel. London: Edward Arnold \& Co. Frye, Northrop (1957). Anatomy of Criticism. Four Essays. Princeton:

Princeton University Press.

Frye, Northrop (1969), New Directions from Old. In Murray, Henry A. Ed. Myth and Mythmaking: 115-131. Boston: Beacon Press. 
Fuller, J.F.C. (1926). The Foundations of the Science of War. London: Hutchinson \& CO (Publishers) LTD.

Genette, Gerard (1980). Narrative Discourse. Translated from French by Jane E. Levin. Oxford: Basil Blackwell.

Genette, Gerard (1993). Fiction and Diction. Translated from French by Catherine Porter. Ithaca: Cornell University Press.

Greimas, Algirdas-Julien (1983). Structural Semantics: An Attempt at a Method. Lincoln and London: University of Nebraska Press.

Gutterman, David S. (2005), Prophetic Politics. Christian Social Movements and American Democracy. Cornell University Press. Ithaca and London.

Hanska, Jan (2012). Reagan's Mythical America: Storytelling as Political Leadership, Palgrave Macmillan. New York.

Herman, David (1999). Introduction. In Herman, David Ed. Narratologies: New Perspectives for Narrative Analysis. 1-30. Ohio State University Press. Columbus.

Herman, David (2002). Story Logic: Problems and Possibilities of Narrative. Lincoln and London: University of Nebraska Press.

Jameson, Fredric (1967) [2002]. The Political Unconscious; Narrative as a socially symbolic act. London and New York: Routledge,

Jameson, Fredric (1984). Foreword. In Lyotard, Jean-Francois: The Postmodern Condition: A Report on Knowledge. Translated by Geoff Bennington and Brian Massumi. Manchester: Manchester University Press.

Jomini, Antoine Henri de (1992). The Art of War, London: Greenhill Books.

Kuhn, Thomas S. (1970). The Structure of Scientific Revolutions. Second Edition, Enlarged. Chicago: University of Chicago Press.

Labov, William - Waletzky, Joshua (1967) [2006], Narrative Analysis: Oral Versions of Personal Experience. In Sage Benchmarks in Social Research Methods - Narrative Methods, Volume 1, Narrative Perspectives, eds. Paul Atkinson \& Sara Delamont. London: Sage Publications.

Lauerma (1977), Sotahistorian tutkimuksen problematiikkaa ja metodiikkaa, In Tiede ja Ase - Suomen Sotatieteellisen Seuran vuosijulkaisu 35/1977: 73-115

Lyotard, Jean-Francois (1984). The Postmodern Condition: A Report on Knowledge. Translated by Geoff Bennington and Brian Massumi. Manchester: Manchester University Press.

Lyotard, Jean-Francois (1993). The Postmodern Condition. Minneapolis: Minnesota University Press.

Lyotard, Jean-Francois (1997). Postmodern Fables. Transl. Georges Van Den Abbeele. Minneapolis and London: University of Minnesota Press. 
MacIntyre, Alasdair (1984). After Virtue: A Study in Moral Theory. Notre Dame: University of Notre Dame Press.

Martin, Wallace (1987). Recent Theories of Narrative. Ithaca and London: Cornell University Press.

Ochs, Elinor - Lisa Capps, (2001). Living Narrative; Creating Lives in Everyday Storytelling. Cambridge: Harvard University Press.

Phelan, James (1996). Narrative as Rhetoric: Technique, Audiences, Ethics, Ideology. Columbus: Ohio State University Press.

Polkinghorne, Donald E. (1988). Narrative Knowing and the Human Sciences. Albany: State University of New York Press.

Prince, Gerald (1992). Narrative as Theme: Studies in French Fiction. Lincoln: University of Nebraska Press.

Propp, Vladimir (1968). Morphology of the Folktale. Translated by Laurence Scott. Austin: University of Texas Press.

Rabinowitz, Peter (1987). Before Reading; Narrative Conventions and the Politics of Interpretation. Ithaca and London: Cornell University Press.

Ricoeur, Paul (1995). Figuring the Sacred: Religion, Narrative and Imagination. Minneapolis: Fortress Press.

Riessman, Catherine Kohler (1993). Narrative Analysis. Qualitative Research Methods Series 30. London: SAGE.

Riessman, Catherine Kohler (2004). Accidental cases: Extending the concept of positioning in narrative studies. In Bamberg Michael Andrews, Molly Eds. (2004) Considering Counter-Narratives; Narrating, resisting, making sense. Studies in Narrative, Volume 4: 3338. Philadelphia: John Benjamin Publishing Company.

Rimmon-Kenan, Shlomith (1983). Narrative Fiction: Contemporary Poetics. London and New York: Methuen.

Sawyer, Ralph D. ed. (1993). The Seven Military Classics of Ancient China. Boulder: Westview Press.

Todorov, Tzvetan (1981). Introduction to Poetics. Minneapolis: University of Minnesota Press.

Triandafillov, Vladimir K. (1994). The Nature of the Operations of Modern Armies. Translated by William A. Burhans. Portland: Frank Cass.

Vego, Milan (2009). Joint Operational Warfare: Theory and Practice. Annapolis: Naval War College Press.

White, Hayden (1973). Metahistory: The Historical Imagination in Nineteenth-Century Europe. Baltimore: Johns Hopkins Press. 